\title{
The immune system as target for subclinical lead related toxicity
}

\author{
Alf Fischbein, Peter Tsang, Jiin-Chyuan J Luo, J George Bekesi
}

During the past two decades, scientific interest and public health concern have shifted their focus from issues connected with overt clinical lead disease to the detection of subtle clinical and biochemical abberations. ${ }^{1}$ This has brought about a change in the thinking on the health risks that are associated with lead toxicity. ${ }^{23}$ Although major emphasis has been set on lead hazards among pediatric populations, there has also been a gradual lowering of the occupational biological standards in many countries.

The several investigations that have shown an association between low level, community related exposure to lead and impairment in child development have provided a strong scientific basis for the decision of the Centers for Disease Control in the United States to define lead toxicity at a blood lead concentration of $10 \mathrm{mcg} / \mathrm{dl}^{4-6} \mathrm{By}$ analogy, reports that neurotoxic effects and abnormalities in the male reproductive system of workers exposed to lead can be detected at blood lead concentrations below that at which removal from exposure is usually mandated, begin to question the safety of blood lead standards that are widely accepted as safe. ${ }^{7-9} \mathrm{~A}$ deja vu from the 1970s, but this time it concerns even lower blood lead concentrations! $!^{10}$

As the scientific spectrum of effects induced by lead has been widened, toxic effects of lead have also been detected in organ systems that historically were not part of the clinical features of lead poisoning. Mechanisms of action of characteristic effects are being studied in greater detail as well. ${ }^{11}$ Although many biochemical and molecular perturbations caused by lead have been studied in experimental

Division of Environmental and Occupational Medicine, Mount Sinai School of Medicine of the City University of New York, New York, NY 10029, USA

A Fischbein, J-C J Luo

Immune Biology Laboratory, Department of Neoplastic Diseases, Mount Sinai School of Medicine, New York, NY 10029, USA

P Tsang, J George Bekesi

Present affiliation: Division of Occupational and Environmental Health, Department of Life Sciences, Bar Ilan University, Ramat Gan 52900, Israel. A Fischbein animals or cell systems, some are beginning to emerge as potentially useful laboratory parameters in the evaluation of persons who are exposed to lead at concentrations primarily associated with subclinical effects. As certain immunotoxic effects tend to appear before traditional toxicological manifestations, they have the potential to serve as early warning mechanisms of impending clinical disease.

Lead has been evaluated extensively in animal studies with regard to its effects on the immune system. ${ }^{12}$ Although few immunotoxicological investigations have been made on persons exposed to lead, the available information indicates that immunotoxic abnormalities induced by lead exist in humans as well. A profile characterised by an increased number of B lymphocytes and a decline in IgM concentrations has been suggested by some investigators. ${ }^{13}$

We have examined a group of firearm instructors and present preliminary findings on immunotoxic manifestations associated with their occupational exposure to lead.

Fifty four instructors volunteered and underwent immunological tests that included analysis of surface phenotypes of mononuclear cells and assessment of lymphocyte functions. ${ }^{14}{ }^{15}$ Two groups of instructors were considered: one group of 15 with blood lead concentrations of $25 \mathrm{mcg} / \mathrm{dl}$ or higher (HL group, mean $31.4(\mathrm{SD}) 4.3$ ) and another group with a mean blood lead concentration of 14.6 (SD) $4.6 \mathrm{mcg} / \mathrm{dl}$ (LL group).

Considerable reductions in the percentage and absolute number of circulating $\mathrm{T}$ cells $\left(\mathrm{CD}^{+}\right)$and $\mathrm{T}$ helper cells $\left(\mathrm{CD}^{+}\right)$were noted in the $\mathrm{HL}$ group with lesser reductions in the LL group (table). A significant reduction in the $\mathrm{T}$ helper cell $\left(\mathrm{CD4}^{+}\right) / \mathrm{T}$ suppressor cell $\left(\mathrm{CD8}^{+}\right)$ratio in the $\mathrm{HL}$ group was caused by a decrease in $\mathrm{T}$ helper cells $\left(\mathrm{CD}^{+}\right)$ without simultaneous increase in $\mathrm{T}$ suppressor cells $\left(\mathrm{CD8}^{+}\right)$. Similar findings were noted for selected lymphocyte functional parameters-that is, pronounced reduction of PHA induced mitogenic responses in the HL group and a lesser impairment in the LL group. The results of these studies and other detailed investigations of $\mathrm{B}$ cell $\left(\mathrm{CD}_{2} \mathrm{O}^{+}\right)$function, mixed lymphocyte culture, and mechanisms of actions will be presented elsewhere.

Our initial results suggest the existence of lead 
Table Lymphocyte surface markers (mean SD) in firearm instructors exposed to lead and controls

\begin{tabular}{|c|c|c|c|}
\hline & Controls & $L L$ group $(<25 \mathrm{mcg} / \mathrm{dl})$ & $H L_{\text {group }}(\geqslant 25 \mathrm{mcg} / \mathrm{dl})$ \\
\hline $\begin{array}{l}\text { T cells (CD3): } \\
\% \\
\text { Absolute No }\end{array}$ & $\begin{array}{r}72 \cdot 6(6 \cdot 0) \\
1679(522)\end{array}$ & $\begin{array}{l}57 \cdot 4(12 \cdot 2) \dagger \dagger \dagger \\
1464(744)\end{array}$ & $\begin{array}{l}46 \cdot 9(11 \cdot 4)^{\star \star \star}+\dagger \dagger \\
1209(333)^{\star} \dagger \dagger\end{array}$ \\
\hline $\begin{array}{l}\text { T helper Cells (CD4): } \\
\% \\
\text { Absolute No }\end{array}$ & $\begin{array}{c}45 \cdot 5(5 \cdot 6) \\
1056(346)\end{array}$ & $\begin{array}{l}30 \cdot 6(9 \cdot 1) \dagger+\dagger \\
779(405) \dagger \dagger\end{array}$ & $\begin{array}{c}21 \cdot 4(9 \cdot 0)^{\star \star \star \star}+\dagger \dagger \\
554(264)^{\star}+\dagger \dagger\end{array}$ \\
\hline $\begin{array}{l}\text { T suppressor cells (CD8): } \\
\text { \% } \\
\text { Absolute No }\end{array}$ & $\begin{array}{l}25 \cdot 7(7 \cdot 3) \\
604(274)\end{array}$ & $\begin{array}{l}23 \cdot 1(8 \cdot 7) \\
557(205)\end{array}$ & $\begin{array}{r}25 \cdot 4(8 \cdot 6) \\
659(245)^{\star}\end{array}$ \\
\hline
\end{tabular}

${ }^{\star} \mathrm{p}<0.1 ;{ }^{\star \star \star} \mathrm{p}<0.01 ;$ HL group $v$ LL group. $\dagger \dagger \mathrm{p}<0.01 ; \dagger \dagger \mathrm{p}<0.002 v$ controls.

related immunotoxic effects, primarily on $\mathrm{T}$ lymphocytes $\left(\mathrm{CD}^{+}\right)$and $\mathrm{T}$ helper cells $\left(\mathrm{CD}^{+}\right)$. The intensity of abnormalities was associated with the degree of lead absorption, and the study seems to identify immunotoxic effects at blood lead concentrations of $25 \mathrm{mcg} / \mathrm{dl}$ and higher.

The detection of subtle and subclinical changes will continue to be of the highest priority as ingredients of preventive occupational and community screening programmes to identify persons at high risk of disease associated with lead. Assessment of immune functions may be an additional complementary tool in the evaluation, at an early stage, of subtle and potentially reversible effects. This approach can add appreciably to the efforts in preventing lead poisoning. Until further efficient control of exposure has been achieved, occupational and community based lead poisoning can unfortunately not yet be incorporated into the "history texts" where it should belong. ${ }^{16}$

Requests for reprints to: Professor Alf Fischbein, Division of Occupational and Environmental Health, Department of Life Sciences, Bar Ilan University, Ramat Gan 52900, Israel.

1 Goyer RA. Lead toxicity: from overt to subclinical to subtle health effects. Environ Health Perspect 1990;86:177-81.

2 US Department of Health and Human Services, Public Health Service, Agency for Toxic Substances and Disease Registry (ATSDR). Toxicological profile for lead. Atlanta, GA: ATSDR, 1990. (publ No. ATSDR/TP-88/17.)

3 Lippmann $M$. Lead and human health: background and recent findings. Environ Res 1990;51:1-24.
4 US Department of Health and Human Services. Agency for Toxic Substances and Disease Registry. The nature and extent of lead poisoning in children in the United States: Atlanta, GA: a report to Congress, 1988.

5 Needleman HL, Gatsonis CA. Low-level lead exposure and the IQ of children. Journal of the American Medical Association. 1990;263:673-8.

6 US Department of Health and Human Services. Centers for Disease Control: Preventing lead poisoning in young children. Atlanta, GA: USDHHS, October 1991.

7 Stollery BT, Broadbent DE, Banks HA, Lee WR. Short term study of cognitive functioning in lead workers. Br J Ind Med 1991;48:739-49.

8 Wildt K, Eliasson R, Berlin M. Effects of occupational exposure to lead on sperm and semen. In: Clarkson TW, Nordberg CF, Sager PR, eds. Reproductive and developmental toxicity of metals. New York: Plenum Press 1983;279-300.

9 Lindbohm ML, Sallmen M, Antilla A, Taskinen H, Hemminki K. Paternal occupational lead exposure and spontaneous abortion. Scand J Work Environ Health 1991;17:95-103.

10 Seppäläinen AM, Tola S, Hernberg S, Kock B. Subclinical neuropathy at "safe" levels of lead exposure. Arch Environ Health 1975;30:180-3.

11 Hajem S, Moreau T, Hannaert $P$, et al. Influence of environmental lead on membrane transport in a French urban male population. Environ Res 1990;53:105-18.

12 Luster MI, Faith RE, Kimmel CA. Depression of humoral immunity in rats following chronic developmental lead exposure. J Environ Pathol Toxicol 1978;1:397-402.

13 Coscia GC, Discalzi G, Ponzetti C. Immunological aspects of occupational lead exposure. Med del Lavoro 1987;78:360-4.

14 Tsang P, Wallace JI, Roboz JP, Sei Y, Bekesi JG. Immune dysfunctions and therapeutic interventions in patients with acquired immune deficiency syndrome and AIDS related complex. Mt Sinai J Med 1987;54:121-8.

15 Tsang $P$, Sei $Y$, Bekesi JG. Isoprinosine induced modulation of $\mathrm{T}$-helper cell subset and antigen presenting monocytes $(\mathrm{Leu} \mathrm{M} 3+\mathrm{Ia}+)$ resulted in improvement of $\mathrm{T}$ and $\mathrm{B}$ lymphocyte function in vitro in ARC and AIDS patients. $J$ Clin Immunol Immunopathol 1987;45:166-76.

16 Needleman HL. Childhood lead poisoning: a disease for the history texts. Am J Public Health 1991;81:685-7 (editorial).

Accepted 13 April 1992 